\title{
FEEDING HABITS AND CONDITION OF TWO LANDLOCKED POPULATIONS OF ALLIS SHAD (ALOSA ALOSA) IN PORTUGAL.
}

\author{
M.J. CORREIA (1), J.L. COSTA (1), C. TEIXEIRA (1), P.R. ALMEIDA (1, 2), \\ I. DOMINGOS (1), M.J. COSTA (1)
}

(1) Instituto de Oceanografia da Faculdade de Ciências de Lisboa, R. Ernesto Vasconcelos, Campo Grande, 1749-016 LISBOA, Portugal.

(2) Departamento de Biologia, Universidade de Évora, 7002-554 ÉVORA, Portugal.

E-mail : zitasia@fc.ul.pt

Reçu le 25 septembre 2000

Accepté le 08 juin 2001

Received 25 September, 2000

Accepted 08 June, 2001

\begin{abstract}
Only three cases of landlocked populations of allis shad (Alosa alosa L.) were reported until the present, being two of them in Portugal. In this paper, data on the feeding habits and condition of these two populations sampled between 1998 and 1999 are presented.
\end{abstract}

Both populations are zooplanktivorous, with cladocerans (Family Daphniidae) and cyclopoid copepods (Cyclops sp.) as the preferential prey for both adults and juveniles from Aguieira reservoir, while in Castelo do Bode adults feed preferentially on calanoid copepods (Copidodiaptomus albidus) and cladocerans (Family Daphniidae).

Landlocked adults present lower condition than the migrating ones, while juveniles from the Aguieira reservoir show a better condition than the juveniles captured in the Mondego estuary. Portugal.

Key-words : Alosa alosa, landlocked populations, feeding habits, condition,

\section{ALIMENTATION ET COEFFICIENT DE CONDITION DES INDIVIDUS DE DEUX POPULATIONS LACUSTRES D'ALOSE (ALOSA ALOSA) AU PORTUGAL.}

\section{RÉSUMÉ}

Jusqu'à présent on ne connaît que trois populations d'alose (Alosa alosa L.) bloquées en eau douce, dont deux au Portugal. Dans cet article sont présentées les données sur les habitudes alimentaires et les coefficients de condition des individus de deux populations portugaises échantillonnées entre 1998 et 1999 dans deux lacs.

Les deux populations se nourrissaient de zooplancton. A Aguieira les proies préférentielles des adultes et des juvéniles étaient les cladocères (Famille Daphnidae) et les copépodes cyclopodes (Cyclops sp.), tandis qu'au réservoir de Castelo do Bode la 
nourriture préférée des adultes était surtout constituée de copépodes calanoides (Copidodiaptomus albidus) et de cladocères (Famille Daphnidae).

Les populations adultes bloquées en eau douce avaient un coefficient de condition inférieur à celui des populations migratoires, tandis que le coefficient de condition des juvéniles du réservoir d'Aguieira était meilleur que celui des juvéniles capturés dans l'estuaire du Mondego.

Mots-clés : Alosa alosa, populations lacustres, alimentation, condition, Portugal.

\section{INTRODUCTION}

The allis shad (Alosa alosa, L.) is an anadromous clupeid whose populations suffered a severe reduction in the last decades. In the beginning of the $20^{\text {th }}$ century its distribution ranged from Iceland and North Europe until the Northeastern Mediterranean and the North of Africa, being nowadays rare in North Europe and British Islands, and extinct in several European rivers (QUIGNARD and DOUCHEMENT, 1991). In Portugal their populations have also decreased, especially in the rivers from the south (e.g. Tejo and Guadiana rivers) (COSTA et al., 2001). One of the main factors responsible for this decline is the construction of dams and weirs (ALEXANDRINO, 1996), which obstruct their upstream migration. These obstacles have caused the reduction of spawning grounds, but on the other hand, have led to the establishment of landlocked populations of allis shad upstream those constructions, within the reservoir areas.

Although there are not many landlocked populations in the genus Alosa, TREWAVAS (1938) described populations from the Irish lakes (Alosa fallax killarnensis, Regan), and BERG and GRIMALDI (1966) worked with populations from the Italian lakes (Alosa fallax lacustris, Fatio). The only populations of $A$. alosa known to be locked are those from the lake EI Kansera in Morocco (FURNESTIN, 1952 ; FURNESTIN and VINCENT, 1955 ; LAHAYE, 1960, 1966), and from Castelo do Bode and Aguieira reservoirs in Portugal (EIRAS, 1981, 1983 ; COLLARES-PEREIRA et al., 1999 ; COSTA et al., 2001). The Portuguese landlocked populations of allis shad exist in the Castelo do Bode reservoir (Tagus basin) since 1951, and in the Aguieira (Mondego basin) since 1981, when the dams were constructed.

As it is stressed by TAVERNY (1991), SABATIÉ (1993) and ALEXANDRINO (1996), several studies on the biology of European shads have been carried out, but only a few refer to the feeding ecology of these species (CASSOU-LEINS and CASSOU-LEINS, 1981 ; APRAHAMIAN, 1988, 1989 ; TAVERNY, 1991 ; ASSIS et al., 1992 ; SABATIÉ, 1993), and there are even less for landlocked populations (BERG and GRILMALDI, 1966).

Most of the research done on the feeding ecology of landlocked populations of the genus Alosa deals with the effect of the alewife (Alosa pseudoharengus, Wilson) in the North American freshwater fishes and zooplankton communities, since this species has become established in many inland lakes of this continent (HUTCHINSON, 1971). Competition with alewives for zooplankton, or predation by alewives on eggs and larvae of native planktivorous fish have been hypothesized as causes for the decline of many of the native species (SMITH, 1970 ; BRANDT et al., 1987 ; ECK and WELLS, 1987), and several authors refer that size-selective predation by alewives has restructured zooplankton communities in the North American inland lakes (WELLS, 1970 ; HUTCHINSON, 1971 ; WARSHAW, 1972 ; VIGERSTAD and COBB, 1978 ; EVANS, 1986 ; BROOKS and DODSON, 1965 ; HEWETT and STEWART, 1989). 
The purpose of this work was to study the food habits of the Portuguese landlocked populations of allis shad, and to evaluate the occurrence of ontogenetic, seasonal or geographical differences on the feeding ecology of this species. The condition of these populations comparatively to the anadromous ones was also analyzed.

\section{MATERIAL AND METHODS}

The study was conducted in the Tagus and Mondego basins (Figure 1). Castelo do Bode dam, with a 3530 ha reservoir and a gross capacity of $1100,0 \mathrm{hm}^{3}$, is located in the River Zêzere (Tagus basin) and was constructed in 1951. MARQUES and BOAVIDA (1997) classified Castelo do Bode as oligotrophic in 1991 and mesotrophic in 1992 and 1993. Aguieira dam, located in the River Mondego, was concluded in 1981 creating a reservoir with an area of 2000 ha and gross capacity of $450 \mathrm{hm}^{3}$. OLIVEIRA and MONTEIRO (1992) considered this one as a low productive reservoir, with phytoplankton and zooplankton communities comparable to the mesotrophic systems.

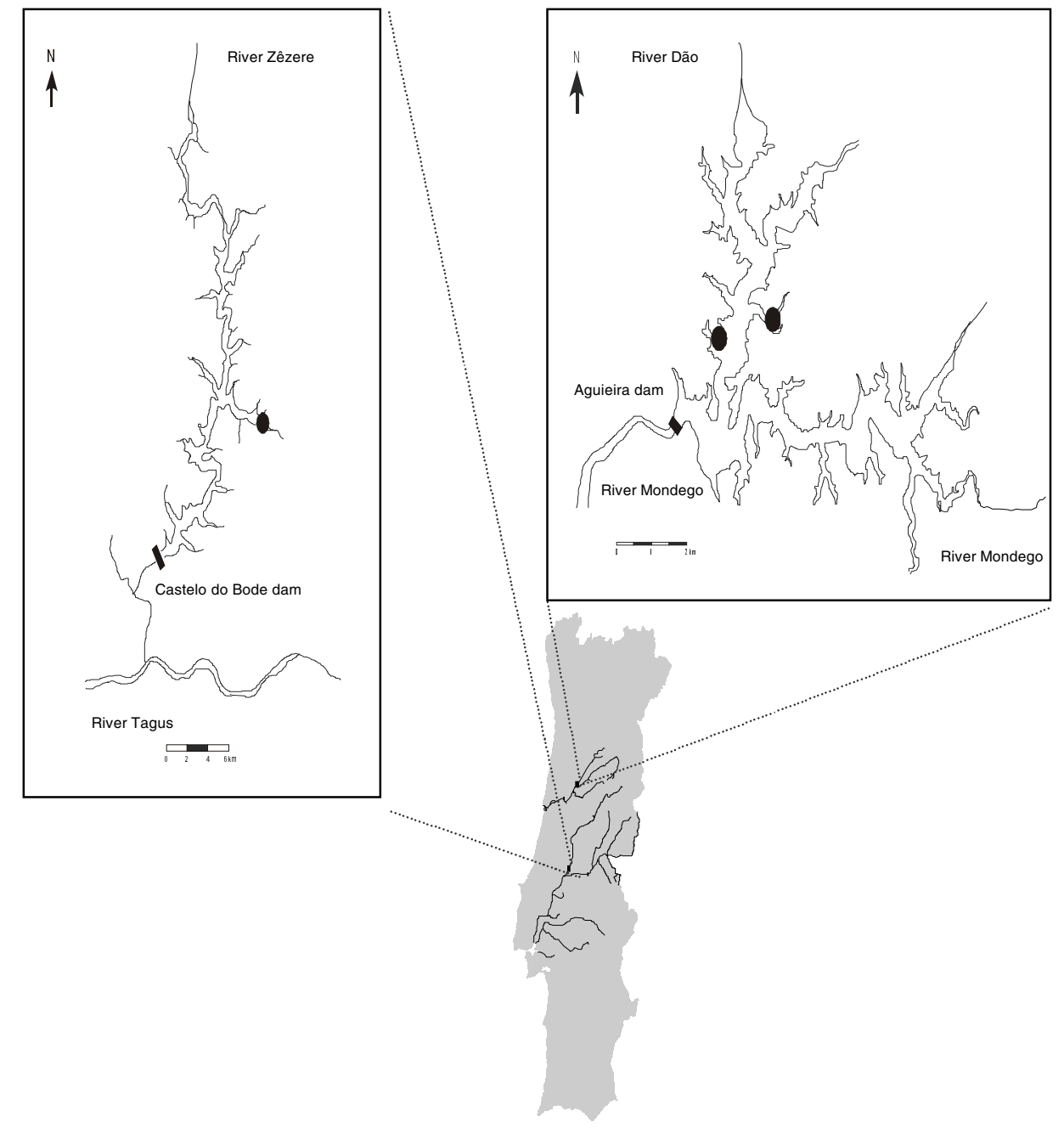

\section{Figure 1}

Map of the study area. Black dots indicate the sampling sites.

\section{Figure 1}

Carte de l'aire d'étude. Les cercles noirs marquent les sites échantillonnés. 
Allis shad specimens were collected from both reservoirs using gill nets $(20-200 \mathrm{~mm}$ knot to knot mesh size ; $2 \mathrm{~m}$ height ; $50 \mathrm{~m}$ long), set perpendicular to the shore at sunset and removed at sunrise in the following day. In Aguieira samples were taken monthly between June 1998 and May 1999, and in the Castelo do Bode collections were made in February and March 1999. After capture the fish were kept frozen. In the laboratory specimens were measured to the nearest $\mathrm{mm}$ ( $\mathrm{TL}$ - total length) and weighed to the nearest $\mathrm{g}$ (EW - eviscerated weight). For the diet analysis a sub-sample was taken and their stomachs were removed and preserved in $70 \%$ alcohol. Prey items were identified to the lowest taxonomic level possible.

The monthly samples from Aguieira reservoir were grouped into seasons (Winter = January-March ; Spring = April-June ; Summer = July-September ; Autumn = October-December), and sorted by length into two groups : (1) juveniles ( $T L \leq 260 \mathrm{~mm}$ ) ; and (2) adults (TL > $260 \mathrm{~mm}$ ).

To evaluate each prey's relative importance the frequency of occurrence (FO percentage of stomachs with content in which a group of prey occurs), according to the ALBERTINI-BERHAUT (1973) method (FO $\geq 50 \%$ - preferential prey ; $10 \% \leq$ FO $<50 \%$ secondary prey ; FO < $10 \%$ - occasional prey) was used. To analyze the feeding activity, the vacuity coefficient (VC) and the fullness index (FI) were calculated according to HYSLOP (1980) : VC - percentage of sample with empty stomachs ; $\mathrm{FI}=$ (weight stomach content / EW) x 100.

The condition factor $(\mathrm{K})$ was computed according to the formula : $\mathrm{K}=\mathrm{EW} \times 10^{5} / \mathrm{TL}^{3}$ (BOLGER and CONNOLLY, 1989).

Friedman and Kruskal-Wallis tests $\left(\chi^{2}\right)$, Mann - Whitney test $(U)$, independence G-test (with Williams or Yates corrections) and Spearman rank-order correlation coefficient $(r)$, were employed in the statistical treatment of the data (SIEGEL and CASTELLAN, 1988 ; SOKAL and ROHLF, 1995). All tests were performed using a level of significance of 0,05 .

\section{RESULTS}

\section{Diet}

A total of 585 specimens were caught in Aguieira and Castelo do Bode reservoirs, and a sub-sample of 200 and 83, respectively from Aguieira and Castelo do Bode reservoirs, was used in the diet analysis.

The diet of the allis shad collected from both sites was composed of zooplanktonic organisms, benthos and terrestrial and aquatic insects (Figure 2). 


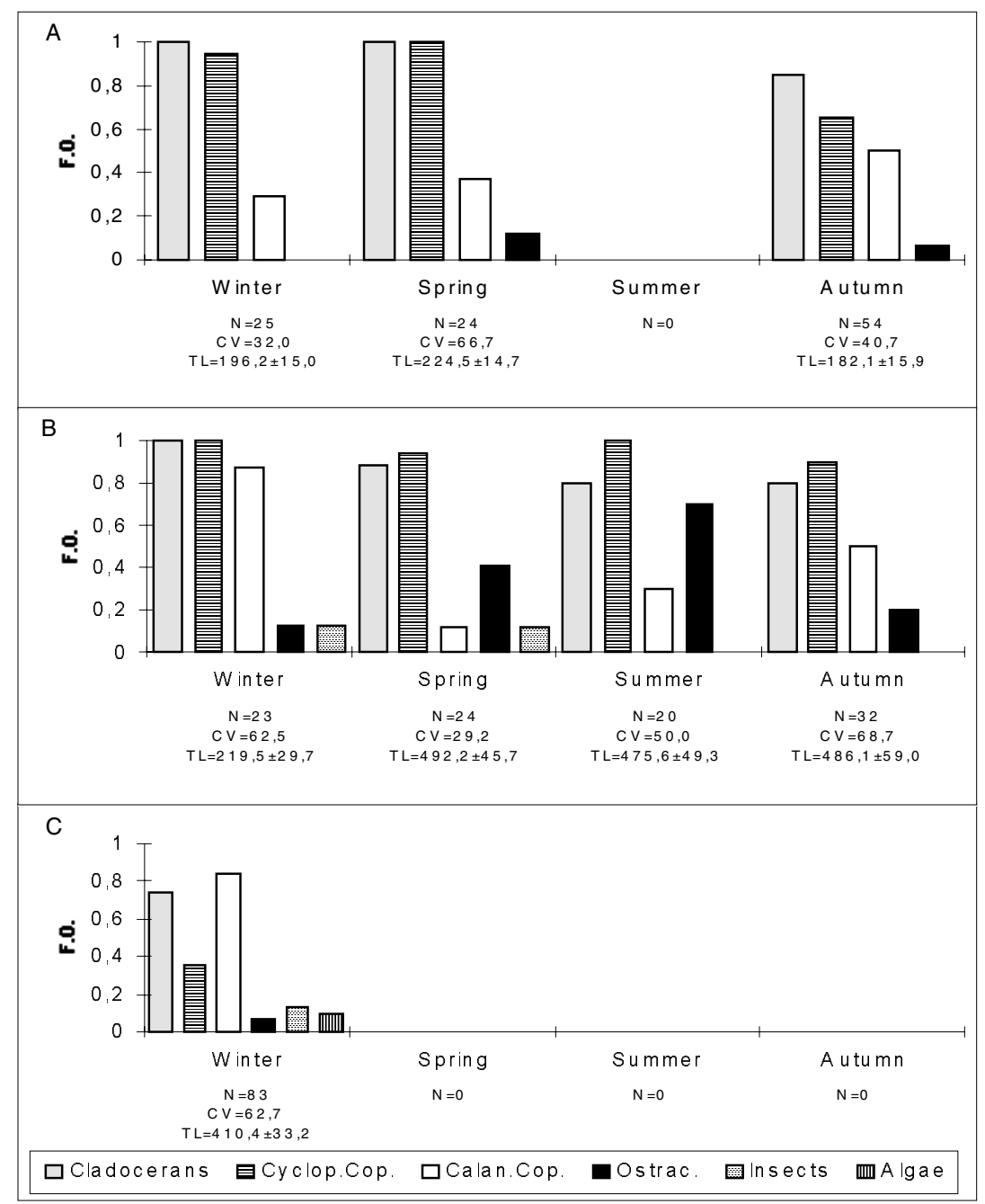

Figure 2

Frequency of occurrence (F.O.) of main prey items for juveniles (A) and adults (B) of allis shad from Aguieira, and for adults from Castelo do Bode (C).

\section{Figure 2}

Fréquence d'occurrence (F.O.) des proies pour les aloses juvéniles (A) et adultes (B) capturées à Aguieira, et pour les adultes capturés à Castelo do Bode (C).

In Aguieira reservoir the cladocerans (Family Daphniidae) and cyclopoid copepods (Acanthocyclops sp.) were the most frequent preys, both for juveniles and adults, while calanoid copepods (Copidodiaptumus numedicus) and ostracods were consumed upon less frequently, being insects rarely ingested. Globally there were no significant differences in the diet along the year, both for juveniles $\left(\chi^{2}=2,533\right.$, d.f. $=2$, n.s. $)$ and adults $\left(\chi^{2}=3,638\right.$, d.f. $=3$, n.s. $)$. Almost all the ingested prey had the same importance all the year in both groups, except the cyclopoid copepods which were less important in the diet of juveniles in Autumn, and the calanoid copepods and ostracods which were highly preyed upon by adults in Winter and Summer, respectively (Table I). 


\section{Table I}

Results from the independence G-test to compare the absolute frequencies of each food item between seasons for the juveniles and adults of allis shad collected in Aguieira reservoir.

\section{Tableau I}

Résultats des G-tests d'indépendance, pour comparer les fréquences absolues des proies entre saisons, chez les juvéniles et adultes d'aloses capturées dans le réservoir Aguieira.

\begin{tabular}{|c|c|c|c|c|}
\hline \multirow{2}{*}{ Prey items } & \multicolumn{2}{|c|}{ Juveniles } & \multicolumn{2}{c|}{ Adults } \\
\cline { 2 - 5 } & $\mathrm{G}_{\text {williams }}^{(\text {(a) }}$ & Test results & $\mathrm{G}_{\text {williams }}^{(b)}$ & Test results \\
\hline Cladocerans & 5,168 & $\underline{\mathrm{Au} \mathrm{Wi} \mathrm{Sp}}$ & 2,608 & $\underline{\text { Au Su Sp Wi }}$ \\
\hline Cyclopoid copepods & $9,126^{\star}$ & $\underline{\mathrm{Au} \mathrm{Wi} \mathrm{Sp}}$ & 1,552 & $\underline{\mathrm{Au} \mathrm{Sp} \mathrm{Wi} \mathrm{Su}}$ \\
\hline Calanoid copepods & 1,948 & $\underline{\text { Wi Sp Au }}$ & $14,307^{\star}$ & $\underline{\text { Sp Su Au Wi }}$ \\
\hline Ostracods & 1,914 & $\underline{\text { Wi Au Sp }}$ & $7,864^{\star}$ & $\underline{\underline{\text { Wi Au Sp Su }}}$ \\
\hline Insects & - & - & 2,840 & $\underline{\text { Wi Sp Su Au }}$ \\
\hline
\end{tabular}

(a) - d.f. $=2 ;$ (b) - d.f. $=3 ;{ }^{*}$ significant values for $p<0,05$.

Wi : Winter ; Sp : Spring ; Su : Summer ; Au : Autumn ; lines join non-significant sub-sets.

Adult and juvenile's diet was correlated in Winter and Autumn (respectively, $r=0,973, n=5, p<0,05$ and $r=0,900, n=5, p<0,05)$ but not in Spring $(r=0,789, n=5$, n.s.), since adults ingested less calanoid copepods and more ostracods than juveniles in the later season. Globally the frequency of ingestion of each prey was similar between adults and juveniles, except for the ostracods which were more frequently ingested by adults (cladocerans: $\mathrm{G}_{\text {Yates }}=0,003$, d.f. $=1$, n.s. ; cyclopoid copepods : $\mathrm{G}_{\text {Yates }}=3,135$, d.f. $=1$, n.s. ; calanoid copepods : $G_{\text {Yates }}=0,000$, d.f. $=1$, n.s. ; ostracods : $G_{\text {Yates }}=7,708$, d.f. $=1, p<0,05 ;$ insects : $G_{\text {Yates }}=2,696$, d.f. $=1$, n.s. $)$.

In Castelo do Bode reservoir the calanoid copepods (Dussartius baeticus) and the cladocerans (Family Daphniidae) were preferential prey, while cyclopoid copepods (Acanthocyclops sp.) played a secondary role in the diet, and ostracods, insects and algae were rarely ingested (Figure 2).

The diet of allis shad adults during the Winter period was not correlated in the two reservoirs ( $r=0,706, n=6$, n.s.), especially for the frequency of ingestion of cyclopoid copepods, which was significantly higher in the adults from Aguieira (cladocerans : $G_{\text {Yates }}=1,534$, d.f. $=1$, n.s. ; cyclopoid copepods : $G_{\text {Yates }}=9,412$, d.f. $=1$, $p<0,05$; calanoid copepods: $G_{\text {Yates }}=0,292$, d.f. $=1$, n.s. ; ostracods : $G_{\text {Yates }}=0,031$, d.f. $=1$, n.s. ; insects $: G_{\text {Yates }}=0,031$, d.f. $=1$, n.s. ; algae $: G_{\text {Yates }}=0,084$, d.f. $=1$, n.s.).

\section{Feeding activity}

The vacuity coefficient of shads from Aguieira showed some differences between seasons (Table II). Juveniles had more stomachs with food in Winter, and showed a significantly higher vacuity coefficient in Spring and Autumn, while adults, on the contrary, had more empty stomachs in Winter, Summer and Autumn, and in Spring the vacuity coefficient was significantly lower. The proportions between adults and juveniles with empty stomachs were not independent on the season (Table II). 


\section{Table II}

Vacuity coefficient (VC) and fullness index (FI) of landlocked populations of allis shad, collected in Aguieira and Castelo do Bode reservoir. The results of the independence G-test and of the Kruskal-Wallis test, for comparisons along the year of the VC and FI are shown, respectively.

\section{Tableau II}

Coefficient de vacuité (VC) et indice de réplétion (FI) des populations de l'alose bloquées aux réservoirs de Aguieira et Castelo do Bode. Résultats des G-tests d'indépendance et des tests Kruskal-Wallis, pour les comparaisons saisonnières de VC et FI.

\section{Vacuity Coefficient}

\begin{tabular}{|c|c|c|c|c|c|c|}
\hline Aguieira & Wi & $\mathrm{Sp}$ & $\mathrm{Su}$ & $\mathrm{Au}$ & $\mathrm{G}_{\text {williams }}$ & Test results \\
\hline & 32,0 & 66,7 & - & $\begin{array}{l}40,7 \\
687\end{array}$ & $6,567^{*(a)}$ & Wi Au Sp \\
\hline Adults & 62,5 & 29,2 & 50,0 & 68,7 & $10,014^{*(b)}$ & Sp Su Wi Au \\
\hline
\end{tabular}

Castelo Bode

Adults $\quad 62,7 \quad-\quad-\quad-$

\section{Fullness Index}

\begin{tabular}{lcccccc}
\hline Aguieira & Wi & Sp & Su & Au & $\chi^{2}$ & Test results \\
Juveniles & 0,40 & 0,33 & - & 0,48 & $2,701^{(\mathrm{c})}$ & Sp Wi Au \\
Adults & 0,16 & 0,29 & 0,37 & 0,13 & $4,870^{(\mathrm{d})}$ & Au Wi Sp Su
\end{tabular}

\section{Castelo Bode}

Adults $0,12 \quad-\quad$ -

(a) : d.f. $=2$; (b) : d.f. $=3 ;$ (c) : $n=102 ;$ (d) : $n=89 ;{ }^{*}$ significant values for $p<0,05$.

Wi : Winter ; Sp : Spring ; Su : Summer ; Au : Autumn ; lines join non-significant sub-sets.

On the other hand, no significant differences were detected in the fullness index along the year for both juveniles and adults (Table II), although there is a similar pattern. However, despite the fact that in Spring the index was similar in both groups, juveniles had a significantly higher fullness index in Winter and Autumn, comparatively to adults (Table III).

The Castelo do Bode population had the same behaviour as the adult specimens caught in Winter in Aguieira reservoir. Both the coefficient of vacuity $\left(G_{\text {Yates }}=0,051\right.$, d.f. $=1$, n.s.) and the fullness index $(U=926,000, n=106$, n.s. $)$ were similar between these populations. 


\section{Table III}

Results of the independence G-test (Yates correction) and the Mann-Whitney test (U), to compare the vacuity coefficient and the fullness index between adults and juveniles from Aguieira reservoir, in each season.

\section{Tableau III}

Résultats des G-tests d'indépendance (correction de Yates) et des tests MannWhitney (U), pour comparer le coefficient de vacuité et l'indice de réplétion entre les juvéniles et les adultes d'aloses capturées à Aguieira, à chaque saison.

\begin{tabular}{|c|c|c|c|}
\cline { 2 - 4 } \multicolumn{1}{c|}{} & Winter & Spring & Autumn \\
\hline Vacuity Coefficient $\left(\mathrm{G}_{\text {Yates }}\right)^{(\mathrm{a})}$ & $4,106^{*}$ & $5,447^{*}$ & $5,320^{*}$ \\
\hline Fullness Index $(\mathrm{U})$ & $171,000^{*(\mathrm{~b})}$ & $128,000^{(\mathrm{c})}$ & $535,000^{\text {(d) }}$ \\
\hline
\end{tabular}

(a) : d.f. $=1 ;$ (b) $: n=48 ;(c): n=37 ;(d): n=85$; * significant values for $p<0,05$.

\section{Condition of fishes}

The condition factor of adult landlocked populations, namely from Aguieira reservoir, is significantly lower than the observed for the migrating adults captured in Mondego and Tejo rivers. Moreover, the Castelo do Bode population has an even lower condition than the allis shad population from Aguieira (Table IV). On the contrary, the juveniles from Mondego estuary showed a significant lower condition factor when compared with the juveniles from the Aguieira reservoir.

\section{Table IV}

Condition factor (K) of allis shad collected in Aguieira and Castelo do Bode reservoirs, and in the rivers Tejo and Mondego. Results from the Mann-Whitney (U) and Kruskal-Wallis tests to compare these values are shown.

\section{Tableau IV}

Coefficient de condition $(K)$ des aloses capturées dans les réservoirs d'Aguieira de Castelo do Bode, et dans les fleuves Tage et Mondego. Résultats des tests Mann-Whitney (U) et Kruskal-Wallis.

\begin{tabular}{|c|c|c|}
\hline Populations & K & Test results \\
\hline Juveniles from Aguieira in Autumn & 0,85 & $U=26,000^{*}(a)$ \\
\hline Juvenile from Mondego estuary in Autumn & 0,61 & \\
\hline A - Adults from Aguieira in Spring & 0,70 & $\chi^{2}=18,307^{\star(b)}$ \\
\hline B - Adults from Mondego river in Spring ${ }^{\circ}$ & 0,83 & $A \underline{C B}$ \\
\hline C - Adults from Tejo river in Spring ${ }^{\circ}$ & 0,80 & \\
\hline $\begin{array}{l}\text { Adults from Aguieira in Winter } \\
\text { Adults from Castelo Bode in Winter }\end{array}$ & $\begin{array}{l}0,64 \\
0,53\end{array}$ & $U=1900,000^{\star}(c)$ \\
\hline
\end{tabular}

(a) : $\mathrm{n}=94$; (b) : d.f. $=2$; (c) : $\mathrm{n}=272$; * significant values for $\mathrm{p}<0,05$; lines join non-significant sub-sets ; ( ${ }^{\bullet}$ unpublished data). 
The seasonal variation of $\mathrm{K}$ values in the adults from Aguieira reservoir did not present any significant change throughout the year (Table V). On the other hand, the condition of juveniles showed a variation, since the $\mathrm{K}$ values are significantly higher in Autumn than in Winter and Spring. Condition is always significantly higher in juveniles comparatively to adults in all seasons (Wi : $U=91,000, n=79, p<0,05 ; \mathrm{Sp}: U=38,000$, $n=41, p<0,05 ; A u: U=401,000, n=218, p<0,05)$.

\section{Table V}

Seasonal condition values $(\mathrm{K})$ of juveniles and adults of allis shad collected in Aguieira reservoir. The results of the Kruskal-Wallis tests to compare these values are also presented.

\section{Tableau V}

Valeurs saisonnières du coefficient de condition $(K)$ des juvéniles et des adultes d'aloses capturées au réservoir d'Aguieira. Résultats des tests Kruskal-Wallis.

\begin{tabular}{ccccccc} 
& Winter & Spring & Summer & Autumn & $\boldsymbol{U}$ & Test results \\
\hline Juveniles & 0,82 & 0,80 & - & 0,87 & $45,072^{*(a)}$ & Sp Wi Au \\
Adults & 0,64 & 0,69 & 0,60 & 0,62 & $6,471^{(b)}$ & Su Au Wi Sp \\
\hline
\end{tabular}

(a) : d.f. $=2$; (b) : d.f. $=3$; * significant values for $p<0,05$; lines join non-significant sub-sets.

\section{DISCUSSION}

Diet analysis of landlocked populations of allis shad from Aguieira and Castelo do Bode reservoirs revealed that these populations are mainly zooplanktivorous, as it was observed in other studies for this and other congeneric species (BROOKS and DODSON, 1965 ; BERG and GRIMALDI, 1966 ; WELLS, 1970 ; HUTCHINSON, 1971 ; VIGERSTAD and COBB, 1978 ; EIRAS, 1981, 1983 ; HEWETT and STEWART, 1989), despite the fact that piscivory has been reported for the alewife (Alosa pseudoharengus) (KOHLER and NEY, 1980 ; BRANDT et al., 1987). The diet of both populations studied is based on cladocerans and copepods, prevailing the cyclopoid copepods in the population from Aguieira reservoir and the calanoid copepods in the Castelo do Bode population.

Although no studies on food selection were performed, both populations seem to consume the more abundant species reflecting each zooplankton community (CABEÇADAS et al., 1980 ; OLIVEIRA and MONTEIRO, 1992 ; CARAMUJO, 1998) and some size-selection on prey should be considered since the great majority of the ingested food items have a similar size. This feature could be due to the disposition of the gill rakers, which act as a plankton sieve. Nevertheless, their feeding activity does not probably produce any effect on zooplankton community, as is was outlined by other authors (BROOKS and DODSON, 1965 ; WELLS, 1970 ; HUTCHINSON, 1971 ; WARSHAW, 1972). BROOKS and DODSON (1965) indicated that selective predation by the alewife on larger species of zooplankton was sufficient to allow smaller zooplankton species to become dominant, and WARSHAW (1972) suggested that Alosa predation, rather than a food decrease, caused the size decrease of zooplanktonic organisms. This effect of landlocked populations of shads on zooplankton communities is apparently null in Portuguese reservoirs, namely in Castelo do Bode, where zooplankton community has been quite stable since the construction of the dam (CABEÇADAS et al., 1980 ; CARAMUJO, 1998). These differences may be related to low abundance of allis shad in Portuguese reservoirs or to specific characteristics of the species $A$. alosa. 
No major ontogenetic changes in the diet of Aguieira shads' population were observed, which is in agreement with BERG and GRIMALDI (1966) studies on landlocked populations of Alosa ficta lacustris. Nevertheless, adults from our study showed a broader diet than juveniles. It has been reported that adult and young-of-the-year alewives exhibit spatial segregation, and this behavior conducts to different diets in the two size classes (BRANDT, 1980 ; JANSSEN and BRANDT, 1980 ; HEWETT and STEWART, 1989). BRANDT (1980) hypothesized that habitat segregation may be an effective way of reducing food competition between immature and adult alewives.

The similarity between the diet of juveniles and adults in the Aguieira reservoir suggests that they may compete for food, especially if the decrease in juvenile feeding intensity on Spring combined with an adults' increase in foraging in this season is taken into consideration. In fact, regardless the reduced seasonal changes in the specific composition of the diet of juveniles and adults, it is apparent that the former feed more actively than adults almost all the year, except during Spring, when adults probably intensify their foraging activity due to the reproductive season, and therefore may be competing directly with the immature fish. This feature could explain the decrease in juvenile's condition in this season, and the increase in the adult's condition. Since no studies on food availability, vertical distribution of both shad and zooplankton communities or even interactions of shads with other fish species were made, these considerations should be carefully regarded. Other explanations apart from competition between the two groups should be taken into consideration namely the existence of spatial segregation of shads, as observed by BRANDT (1980), combined with a differential vertical distribution of zooplankton. Another hypothesis could be a higher efficiency of adults in the filtering process, resulting from a more tight gill raker structure, since in the Spring smaller plankton is available associated with the natural blooms of the season. Finally, some negative interaction between shad juveniles and fish predators could be occurring during the Spring.

The scarcity of food available in the Aguieira and Castelo do Bode, classified as low productive reservoirs (CABEÇADAS et al, 1980 ; OLIVEIRA and MONTEIRO, 1992 ; CARAMUJO, 1998), could result in the very poor condition of adults from landlocked populations when compared with anadromous fish. This has also been reported by EIRAS (1981, 1983) in the 80's referring to the population from Castelo do Bode. Besides the scarcity of food, these differences could also represent an adaptation of shads to the freshwater environment, where they do not have the energy demands that anadromous populations have for the upstream migration to the spawning grounds. It is surprising, however, that juveniles from landlocked populations have a better condition than the anadromous ones, at least in the Autumn. Considering the habitats of both populations, it is not reasonable to think that food availability is the cause to this finding, since estuaries are highly productive ecosystems. However, the juveniles inhabiting estuaries have to deal with constant changes in the salinity gradient that could cause high-energy losses with the osmoregulation process, and lead to this lower condition of fishes. This decrease in the condition factor is well documented namely for salmonids during the smolting process (MCKEOWN, 1984). On the other hand, since juveniles migrate seaward in early Autumn, with the larger individuals being the first to emigrate (APRAHAMIAN, 1988), these results could be biased and represent only the part of the juveniles, namely the smaller specimens, that have not yet gone to the sea.

Aguieira juveniles showed a better condition than adults all year round, probably due to the lowest feeding demands of the former, capable of satisfying their needs despite the scarcity of food in the reservoir. Although the adults in the reservoir could be adapted to the new environment and, as hypothesized before, have naturally a lower condition than migrating ones, despite the availability of food, the seasonal variation of condition of these fishes was in accordance with the reproductive cycle, with the maximum value in Spring, before spawning occurs, and minimum in Summer, after the spawning season. 


\section{CONCLUSION}

Landlocked populations of $A$. alosa are essentially zooplanktivorous. Although some doubts about the existence of intra-specific competition within the Aguieira shad population remain, this hypothesis is consistent with the seasonal values of both feeding intensity and condition in this population.

Unfortunately the studies conducted on landlocked populations gave little importance to the condition of fishes, but this study shows that the landlocked adults have lower condition than the migrating ones. As pointed out, this could reflect the low availability of food in the reservoirs or an adaptation of these specimens to the freshwater environment, where they do not have the energy demands that anadromous populations do to reach the spawning grounds.

To clarify the unsolved questions of this study, it would be extremely important to estimate the abundance of these landlocked populations and conduct studies on selective feeding and vertical distribution of both shads and zooplankton community.

\section{AKNOWLEDGMENTS}

This work was funded by the Fundação para a Ciência e Tecnologia under the project 3/3.2/C.A./1981/95 “Caracterização ecológica e genética de populações portuguesas de sável e savelha (Alosa spp.) e de lampreia (Petromyzon marinus). Bases biológicas para a sua gestão e conservação » and the schoolarship BIC/3584.

\section{REFERENCES}

ALBERTINI-BERHAUT J., 1973. Biologie des stades juvéniles de Téléostéens Mugilidae Mugil auratus Risso 1810, Mugil capito Cuvier 1829 et Mugil saliens Risso 1810. I. Régime alimentaire. Aquaculture, 2, 251-266.

ALEXANDRINO P.J., 1996. Estudo de populações de sável (Alosa alosa L.) e savelha (Alosa fallax Lacépède). Análise de diferenciação interspecífica, subestruturação e hibridização. PhD thesis, University of Porto, Portugal, $185 \mathrm{p}$.

APRAHAMIAN M.W., 1988. The biology of the twaite shad, Alosa fallax fallax (Lacépède), in the Severn estuary. J. Fish Biol., 33 (suppl. A), 144-152.

APRAHAMIAN M.W., 1989. The diet of juvenile and adult twaite shad Alosa fallax fallax (Lacépède) from the rivers Severn and Wye (Britain). Hydrobiologia, 179, 173-182.

ASSIS C.A., ALMEIDA P.R., MOREIRA F., COSTA J.L., COSTA M.J., 1992. Diet of the twaite shad Alosa fallax (Lacépède) (Clupeidae) in the river Tagus estuary, Portugal. J. Fish Biol., 41, 1049-1050.

BERG A., GRIMALDI E., 1966. Biologia dell'Agone (Alosa ficta lacustris) del lago Maaggiore. Mem. Ital. Ist. Idrobiol., 20, 41-83.

BOLGER T., CONNOLLY P.L., 1989. The selection of suitable indices for the measurement and analysis of food condition. J. Fish Biol., 34, 171-198.

BRANDT S.B., 1980. Spatial segregation of adult and young-of-the-year alewives across a thermocline in lake Michigan. Trans. Am. Fish. Soc., 109, 469-478.

BRANDT S.B., MASON D.M., MACNEILL D.B., COATES T., GANNON J.E., 1987. Predation by alewives on larvae of yellow perch in lake Ontario. Trans. Am. Fish. Soc., 116, 641-645.

BROOKS J.L., DODSON S.I., 1965. Predation, body size, and composition of plankton. Science (Washington, D.C.), 150, 28-35. 
CABEÇADAS M.G., CAVACO M.H., MONTEIRO M.T., OliVEIRA M.R., 1980. Limnological study of Castelo do Bode reservoir. Bol. Inst. Nac. Invest. Pescas Lisboa, 4, 5-127.

CARAMUJO M.J., 1998. As comunidades de copépodes planctónicos da bacia do rio Tejo: estrutura e interacções com outras comunidades de zooplanctontes. PhD. Thesis, University Lisbon, Portugal, $153 \mathrm{p}$.

CASSOU-LEINS F., CASSOU-LEINS J.J., 1981. Recherches sur la biologie et l'halieutique des migrateurs de la Garonne et principalement de l'alose, Alosa alosa L. PhD thesis, Institut National Polytechnique de Toulouse, France, $382 \mathrm{p}$.

COLLARES-PEREIRA M.J., COWX I.G., SALES LUÍS T., PEDROSA N., SANTOS-REIS M., 1999. Observations on the ecology of a landlocked population of allis shad in Aguieira reservoir, Portugal. J. Fish Biol., 55, 658-664.

COSTA M.J., ALMEIDA P.R., DOMINGOS I.M., COSTA J.L., CORREIA M.J., CHAVES L., TEIXEIRA C.M., 2001. Present status of the main shads' populations in Portugal. Bull. Fr. Pêche Piscic., 362/363, 1109-1116.

ECK G.W., WELLS L., 1987. Recent changes in lake Michigan's fish community and their probable causes, with emphasis on the role of the alewife (Alosa pseudoharengus). Can. J. Fish. Aquat. Sci., 44 (suppl. 2), 53-60.

EIRAS J.G.,1981. Sur une population de Alosa alosa, poisson migrateur amphibiotique, potamotoque, thalassotrophe, bloquée en eau douce au Portugal. Cybium, 5, 6973.

EIRAS J.G., 1983. Some aspects of the biology of the landlocked population of anadromous shad Alosa alosa L. Publicações do Instituto de Zoologia «Dr. Augusto Nobre », 180, 1-16.

EVANS M.S., 1986. Recent major declines in zooplankton populations in the inshore region of lake Michigan : probable causes and implications. Can. J. Fish. Aquat. Sci., 43, 154-159.

FURNESTIN J., 1952. L'alose d'El Kansera, cas d'une adaptation totale d'une espèce anadrome aux eaux douces. C.R. Acad. Sc. Paris, 234, 2018-2020.

FURNESTIN J., VINCENT A., 1955. Persistance de la phase migratoire chez l'alose marocaine adaptée aux eaux douces. C.R. Acad. Sc. Paris, 240, 355-357.

HEWETT S.W., STEWART D.J., 1989. Zoolplanktivory by alewives in lake Michigan : ontogenetic, seasonal, and historical patterns. Trans. Am. Fish. Soc., 118, 581-596.

HUTCHINSON B.P., 1971. The effect of fish predation on the zooplankton of ten Adirondack lakes, with particular reference to the alewife, Alosa pseudoharengus. Trans. Am. Fish. Soc., 2, 325-335.

HYSLOP E.J., 1980. Stomach contents analysis - review of methods and their application. J. Fish Biol., 17, 411-429.

JANSSEN J., BRANDT S.B., 1980. Feeding ecology and vertical migration of adult alewives (Alosa pseudoharengus) in lake Michigan. Can. J. Fish. Aquat. Sci., 37, 177-184.

KOHLER C.C., NEY J.J., 1980. Piscivory in a land-locked alewife (Alosa pseudoharengus) population. Can. J. Fish. Aquat. Sci., 37, 1314-1317.

LAHAYE J., 1960. Croissance et maturation des ovocytes chez la forme totalement adaptée aux eaux douces de l'alose marocaine (Alosa alosa L.). Rev. Trav. Inst. Pêches Marit., 24, 499-512.

LAHAYE J., 1966. Variations cycliques de l'activité thyroidienne chez des aloses migrant normalement en mer et chez des aloses bloquées en eau douce. Rev. Trav. Inst. Pêches Marit., 30, 347-355.

MARQUES R.T., BOAVIDA M.J., 1997. Monitoring water quality in the Portuguese reservoirs of the river Tejo watershed. Verh. Int. Ver. Limnol., 26, 740-744.

MCKEOWN B.A., 1984. Fish migration. Croom Helm, London, 224 p.

OLIVEIRA M.R.L., MONTEIRO M.T., 1992. «Blooms » de Cyanophyceae na albufeira da Aguieira-efeitos na qualidade da água e no zooplâncton. Rel. Técn. Cient. INIP, 61, $57 \mathrm{p}$. 
QUIGNARD J.P., DOUCHMENT C.I., 1991. Alosa alosa (Linnaeus, 1758). In HOESTLANDT H. (ed.), The freshwater fishes of Europe. Vol. II - Clupeidae and Anguillidae. Aula-Verlag Wiesbaden, Wiesbaden, 89-127.

SABATIÉ M.R., 1993. Recherches sur l'écologie et la biologie des aloses au Maroc. PhD. thesis, Université Bretagne Occidentale, France, $326 \mathrm{p}$.

SIEGEL S., CASTELLAN J.R., 1988. Nonparametric statistics for the behavior sciences. $\left(2^{\text {nd }}\right.$ ed.) McGraw-Hill International Editions, New York, USA, $399 \mathrm{p}$.

SMITH S.H., 1970. Species interaction of the alewife in the Great Lakes. Trans. Am. Fish. Soc., 99, 754-765.

SOKAL, ROHLF, 1995. Biometry. ( $3^{\text {rd }}$ ed.) Freeman and Company, New York, $887 \mathrm{p}$.

TAVERNY C., 1991. Contribution à la connaissance de la dynamique des populations d'aloses (Alosa alosa et Alosa fallax) dans le système fluvio-estuarien de la Gironde : pêche, biologie et écologie. PhD. Thesis, Université Bordeaux I, France, $375 \mathrm{p}$.

TREWAVAS, 1938. The killarney shad or gureen (Alosa fallax killarnensis Regan, 1916). Proc. Linn. Soc. London, 150, 110-112.

VIGERSTAD T.J., COBB J.S., 1978. Effects of predation by sea-run juvenile alewives (Alosa pseudoharengus) on the zooplankton community at Hamilton reservoir, Rhode Island. Estuaries, 1, 36-45.

WARSHAW S.J., 1972. Effects of alewives (Alosa pseudoharengus) on the zooplankton of the lake Wononskopomuc, Connecticut. Limnol. Oceanogr., 17, 816-825.

WELLS L., 1970. Effects of alewife predation on zooplankton populations in lake Michigan. Limnol. Oceanogr., 15, 556-565. 
